международных коммерческих арбитражей в системе источников международного частного права. Исследовано значение судебной и арбитражной практики при решении проблем правоприменения и толкования правовых норм при регулировании частноправовых отношений, составляющих предмет отрасли международного частного права.

Ключевые слова: источники права; судебная и арбитражная практика; судебный прецедент; источники международного частного права; международный коммерческий арбитраж.

\title{
Summary
}

Ernest Gramatskiy. Judicial and arbitration practice as a source of private international law: general provisions.

Nowadays the processes of democratization, liberalization, integration of Ukraine into European and world space take place. The undisputed significance for these processes is the signing of the Association Agreement between Ukraine and the European Union of 27.06.2014. Thus, the rapprochement of Ukraine with the European community, which has taken place in recent years, affects the sphere of private legal relations, which are complicated by a foreign element - the legal relations that make up the subject to international private law.

Having analyzed current doctrine of international private law, we can conclude that nowadays researchers are paying more attention to the role, theoretical and practical issues of judicial and arbitration practice as a source of private international law.

Qualitative changes in legal relations which are the subject to private international law, the transition to other conceptual approaches of law enforcement and legal qualification, accumulation of an extremely voluminous regulatory array, codification of the norms of certain institutes of private international law confirm the relevance of a detailed analysis and study of judicial and arbitration practice as a source of private international law.

Theoretical and practical aspects of judicial and arbitration practice as a source of private international law are analyzed. General approaches to the concept of judicial and arbitration practice as a source of law are considered. The main approaches and positions of scientists on the role, place and importance of the judicial and arbitration practice as a source of private international law are identified. It is emphasized that the mechanism of legal regulation of any branch of law is characterized by the presence of certain defects, which in one way or another complicate the regulation of legal relationships, which include, first of all, gaps in legal regulation, conflicts, etc. That is the reason why the analysis of judicial and arbitration practice as a source of private international law is considerable issue.

Particular attention is paid to the place of practice of international judicial institutions in the system of sources of private international law, including practice of the European Court of Human Rights, and international commercial arbitrations.

The analysis of scientific sources makes it possible to figure out that judicial and arbitration practice should be regarded as a source private international law of subsidiary order, bearing in mind its importance in resolving the problems of law enforcement and the interpretation of legal rules in the regulation of private legal relations which are the subject to private international law. At the same time, particular attention is paid to the practice of international judicial institutions, whose binding decision has been recognized by Ukraine, and international commercial arbitration in disputes arising from international instruments that are the source of private international law. We suppose these problems need special attention and can be considered to be an actual subject of further scientific research.

Key words: sources of law; judicial and arbitration practice; judicial precedent; sources of private international law; international commercial arbitration.

DOI: $10.36695 / 2219-5521.2 .2019 .22$

УДК 347.4

П.Д. ГУЙВАН

Петро Дмитрович Гуйван, кандидат юридичних наук, профресор Полтавського інституту бізнесу, заслужений юрист Украӥни*

ORCID: 0000-0003-3058-4767

\section{ПРАВОВІ ЗАСАДИ ОБМЕЖЕННЯ ДОСТУПУ ДО ПУБЛІЧНОЇ ІНФОРМАЦІЇ}

Постановка проблеми. Інформація в демократичному суспільстві є однією із основних соціальних цінностей. Ї̈ї належне використання, забезпечення інформаційних прав суб'єктів та правова охорона вільного обороту відомостей - засадничі основи для досягнення цілей соціально-економічного та культурного розвитку країни, поліпшення якості життя. Можливість кожного члена суспільства отримати дані стосовно публічних відносин у соціумі гарантує зміцнення єдиного інформаційного простору, мінімізацію різних негативних проявів у діяльності органів влади, таких як зловживання, недбалість, корупція. Власне презумпція відкритості публічної інформації у нас забезпечується приписами закону. Так, у ст. 20 загального Закону України «Про інформацію» зазначено, що будь-яка інформація є відкритою, крім тієї, що віднесена законом до інформації з обмеженим доступом. Право на доступ до інформації є ключовим елементом громадського контролю, дієвим механізмом боротьби з негативними соціальними явищамиํํ․

Особлива увага має приділятися питанням прозорості відомостей, що становлять певний публічний інтерес. Така інформація отримала назву публічної, і за загальним правилом вона також є відкритою. Винятки з цього правила визначаються законом, зокрема, встановлено види інформації, до якої може бути обмеже-

() П.Д. Гуйван, 2019

* Petro Guyvan, Ph.D. in Law, Professor of Poltava Institute of Business, Honored Lawyer of Ukraine 
но доступ: конфіденційна, таємна та службова інформація та сукупність вимог, дотримання яких є обов'язковим для обмеження доступу до таких видів інформації. Зазначені обмеження щодо обороту певних даних $\epsilon$ досить виваженими, вони можуть мати місце тільки у випадках, коли зачіпаються основні засади державного ладу та національної безпеки, невід'ємні основоположні права людини. Скажімо, конфіденційна інформація не може бути поширена, лише коли є загроза інтересам національної безпеки, економічного добробуту та прав людини. Українське законодавство передбачає, що заборона на вільний обіг публічних даних може мати місце при встановлення переваги потенційної шкоди від поширення конфіденційної інформації над правом громадськості знати її (ч. 1 ст. 29 Закону України «Про інформацію»). Такий підхід відтворює принцип пропорційності обмеження права, який $\epsilon$ аспектом верховенства права, передбаченого, зокрема, ч. 2 ст. 10 Конвенції про захист прав людини і основоположних свобод. Саме через детальний аналіз законності підстав, легітимності наявної мети та прийнятності втручання в демократичному суспільстві досліджується правомірність будь-якого обмеження права, в тому числі права на отримання інформації. Дана концепція цілком відповідає практиці Європейського суду з прав людини.

Разом із тим якість чинного законодавства є хоча і дуже важливим, але не достатнім чинником, що забезпечує справедливі та чесні відносини стосовно відкритості доступу до публічної інформації. Має були усталена суспільна потреба у прозорості дій органів влади, яка підтримується бажанням самих публічних суб'єктів сприяти своїй відкритості. Ось цієї складової, що істотно сприяє побудові інформаційного суспільства, поки що в Україні не спостерігається. Суб'єкти владних повноважень державного та місцевого рівня всіляко намагаються утаємничити свою діяльність, у такий спосіб прикриваючи власні помилки, а часто і зловживання. Це супроводжується підтримкою владних структур з боку національного судівництва. Суди, спрямовуючи свою діяльність на захист інтересів влади, що часто мають не соціальне спрямування, а неправомірний захист чиновника, чомусь вважають, що діють в інтересах держави. Насправді ж Україна, стаючи на рейки цивілізаційних демократичних потреб сьогодення, вже чітко сприйняла та задекларувала принципову перевагу захисту інтересів та основних прав особистості над владними інтересами. Тож стан речей, пов'язаний із широким блокуванням прогресу у сфері вільного інформаційного обороту, не відповідає нагальним потребам сьогодення. Яскравим прикладом може слугувати дуже ускладнена, невиправдано заформалізована, а відтак абсолютно недієва система доступу громадян до публічної інформації².

Аналіз останніх досліджень і публікацій. Питання щодо правового забезпечення відкритості обороту публічної інформації неодноразово висвітлювалися в науковій літературі. Можемо згадати праці таких вчених, як Т. Костецька, І. Гнибіденко, С. Додін, Д. Гунін, І. Ібрагімова, А. Грищенко, В. Колісник, Т. Шевченко та інші. Разом із тим у цих роботах головна увага була зосереджена на теоретичному обгрунтуванні та нормативно-правовому врегулюванні питання необхідності вільного доступу кожної особи, яка має публічний чи приватний, пов'язаний із суспільним, інтерес, до відповідної інформації. Натомість мало дослідженою залишається проблематика правового застосування зазначених правил. Адже це якраз і становить реальну проблему нашої національної системи права. Практично не аналізувалися питання дотримання критеріїв пропорційності втручання владних структур у свободу доступу до інформації, що на практиці призводить до свавілля та незаконного обмеження прав людини у коментованій сфері. Вивчення вказаних аспектів інформаційних відносин є метою цієї статті.

Виклад основного матеріалу. Закон України (далі - ЗУ) «Про інформацію» містить низку положень, важливих для реалізації права на доступ до інформації, а саме: дозвіл на поширення інформації з обмеженим доступом, якщо вона є суспільно необхідною, тобто є предметом суспільного інтересу, і право громадськості знати цю інформацію переважає потенційну шкоду від поширення (ч. 1. ст. 29); визначення невичерпного переліку інформації, що становить предмет суспільного інтересу (ч. 2 ст. 29); звільнення від відповідальності за розголошення інформації з обмеженим доступом, якщо суд встановить, що ця інформація є суспільно необхідною (ч. 3 ст. 30).

Як свідчить практика, суб'єкти влади найчастіше відмовляють у доступі до публічної інформації з огляду на те, що, як вони вважають, дана інформація є службовою. Втім, подібні відмови є переважно протизаконними, що порушує інформаційні права особи. Адже за правилом п. 1, 2 ч. 1 ст. 9 ЗУ «Про доступ до публічної інформації» до службової може бути віднесена лише та інформація, яка міститься в документах суб'єктів владних повноважень, що становлять внутрівідомчу службову кореспонденцію, зокрема, доповідні записки, рекомендації, якщо вони пов'язані з розробкою напряму діяльності установи або здійсненням контрольних, наглядових функцій органами державної влади, процесом прийняття рішень і передують публічному обговоренню та/або прийняттю рішення, або відомості, зібрані в процесі оперативно-розшукової, контррозвідувальної діяльності, у сфері оборони країни, яку не віднесено до державної таємниці. Отже, розпорядник інформації перед тим, як зробити висновок стосовно можливого обмеження, мусить зіставити ознаки конкретних даних з тими, які закон кваліфікує як характеристики службової інформації. Якщо чіткого збігу не буде, суб'єкт влади не вправі визнавати інформацію обмеженою в доступі. Слід також враховувати, що окремі встановлені законом чинники, які стосуються обмежень, можуть з часом втратити своє кваліфікуюче значення. Так, після публічного обговорення чи прийняття рішення відомості, що містяться в документах, які створювались або знаходяться у володінні розпорядника і стосуються підготовки, обговорення, розгляду та прийняття цього рішення, втрачають статус службової інформації.

Власне, взагалі будь-яка можливість обмеження доступу до інформації за приписом ст. 6 спеціального закону може виникнути тільки тоді, коли дотримано сукупність таких вимог: 1) це робиться виключно в інте- 
ресах національної безпеки, територіальної цілісності або громадського порядку з метою запобігання заворушенням чи злочинам, для охорони здоров'я населення, для захисту репутації або прав інших людей, для запобігання розголошенню інформації, одержаної конфіденційно, або для підтримання авторитету і неупередженості правосуддя; 2) розголошення інформації може завдати істотної шкоди цим інтересам; 3) шкода від оприлюднення такої інформації переважає суспільний інтерес в ії отриманні. Не важко помітити, що закон вказує на обов'язкову наявність сукупності вказаних у ст. 6 Закону ознак. Один із таких чинників, який обов'язково має бути присутнім, аби інформація визнавалася обмеженою в доступі, є вчинення обмеження в інтересах національної безпеки, територіальної цілісності або громадського порядку. Іншим обов'язковою ознакою має бути факт того, що шкода від оприлюднення такої інформації переважає суспільний інтерес в ії отриманні.

Ось такі, досить складні обов'язки щодо доведення можливого обмеження доступу до публічної інформації, покладає на органи влади законодавство. У разі виникнення з даного приводу судового спору за ст. 77 КАСУ презумпція доказування в адміністративному процесі покладається на відповідача - суб'єкта владних повноважень. Якщо йому не вдасться довести наявність означених у законі підстав інформаційних обмежень, відомості вважаються відкритими, і доступ до них мусить мати кожна особа, яка проявляє відповідний публічний інтерес. Насправді все далебі не так райдужно. Суб'єкти владних повноважень абсолютно не обтяжують себе будь-якими доказами наявності загрози від надання інформації запитувачу національній безпеці, територіальній цілісності або громадському порядку та ніяким чином не аргументують факт перевищення шкоди від оприлюднення такої інформації над суспільним інтересом в їі отриманні. Водночас національні суди взагалі бездоказово визнають інформацію обмеженою, а іноді взагалі приймають таке рішення без оцінки доказів, керуючись виключно «авторитетністю» позиції владного органу.

Між тим, за законом навіть безспірне визнання певної інформації службовою і навіть таємною або конфіденційною далебі не означає, що вона не може бути надана для використання конкретній особі. Важливо розуміти, що відповідність одному із зазначених вище пунктів не створює обов'язку автоматичного віднесення інформації до обмеженої. Відтак, не може бути відмовлено у доступі до інформації лише тому, що відповідний вид інформації включено до переліку відомостей, які становлять службову інформацію. Нормативний акт вказує, що у разі суспільної потреби у цих відомостях вони також можуть стати публічно доступними: у кожному випадку, коли конкретній інформації надається статус «для службового користування», розпорядником інформації обов'язково має застосовуватися так званий «трискладовий тест». Зміст даної процедури давно визначений та усталений, у тому числі і у міжнародних правилах, які регулюють справедливий доступ особи до інформації, що має суспільний інтерес. Застосування «трискладового тесту» повинно здійснюватись таким чином: 1) встановлення відповідності обмеження доступу до запитуваної конфіденційної інформації одному із захищених інтересів; 2) встановлення можливості завдання істотної шкоди цим інтересам; 3) порівняння цієї потенційної шкоди з правом громадськості знати цю інформацію. Якщо шкода не переважає суспільний інтерес в доступі до інформації, то обмежена інформація може бути розголошена $\mathrm{i}$ доступ до неї не може бути обмежений. Коли під час розгляду справи в суді буде з'ясовано, що відмовляючи у задоволенні запиту на інформацію розпорядник не застосовував «трискладового тесту» або застосував його лише частково, то це не є підставою для визнання такої відмови розпорядника протиправною. Але суд у такому разі може зобов'язати розпорядника інформації повторно розглянути запит і надати на нього обгрунтовану відповідь із застосуванням «трискладового тесту» відповідно до частини другої ст. 6 Закону3 .

Отже, тільки після застосування «трискладового тесту» допустиме обмеження доступу до публічної інформації, заборона на поширення якої встановлена безпосередньо законом. Відмова у задоволенні запиту на інформацію повинна бути мотивованою, тобто у відмові розпорядник інформації зобов'язаний обгрунтувати наявність підстав обмеження у доступі, які становлять зміст «трискладового тесту». У цьому сенсі відмова $є$ обгрунтованою тільки тоді, якщо розпорядник чітко вказує, якому саме з інтересів загрожує розголошення запитуваної інформації, в чому полягає істотність шкоди цим інтересам від ії розголошення, чому шкода від оприлюднення такої інформації переважає право громадськості знати цю інформацію в інтересах національної безпеки, економічного добробуту чи прав людини. Інакше кажучи, якщо навіть розпорядникові вдалося б показати, що розголошення інформації може завдати суттєвої шкоди легітимній цілі, інформація однаково підлягає оприлюдненню, якщо суспільна користь від їі розголошення переважає шкоду. Наприклад, певна інформація може бути приватною за походженням, але водночас розкривати дані щодо високого рівня корупції в уряді. У таких випадках шкода легітимній цілі повинна бути порівняна із суспільним інтересом в оприлюдненні цих відомостей. Там, де суспільний інтерес переважає, закон повинен захищати оприлюднення інформації4.

Дотримання вказаних вище вимог є обов'язковим у демократичній державі. Однак українські розпорядники взагалі не переймаються такими складними правовими поняттями, як «трискладовий тест», а відмову у доступі, якщо колись і обгрунтовують, то лише тим, що особисто вважають інформацію закритою для ознайомлення. До прикладу відповідач у справі № 800/333/17 за позовом про визнання незаконною відмови надати публічну інформацію - Вища кваліфікаційна комісія суддів України взагалі у процесі і досудовій переписці ніколи не ставив такі складні оціночні питання на розгляд, а словосполучення «трискладовий тест» жодного разу не використовувалося, не коментувалося чи якось аргументувалося. Всю роботу щодо обгрунтування неаргументованих заперечень проти позову замість відповідача зробив Верховний Суд. У такий спосіб судовий орган порушив низку принципів справедливого судочинства, таких як безсторон- 
ність, рівність сторін, побудова вердикту виключно на підставі доказів тощо. До цього слід також додати, що правило про «трискладовий тест» вимагає не лише зазначення правової підстави для обмеження інформації у доступі (наприклад, загрози підтримання авторитету і неупередженості правосуддя), а й аргументовано обгрунтувати і таким чином доказати ії. Якщо відповідач цього не робив і не збирався робити, то це повинен був здійснити суд, який у даному процесі виступав у ролі його адвоката. Насправді жодного обгрунтування загрози державному управлінню, не кажучи вже про іiі перевищення публічного інтересу від відкриття інформації, у коментованому рішенні від 8 лютого 2018 р. у справі № 800/333/17 немає 5 . I передовсім тому, що його об'єктивно не існувало.

Таким чином, одна із важливих проблем, пов'язана із забезпеченням права громадян на доступ до публічної інформації, - це наявність та широке неправомірне застосування грифів обмеження доступу до інформації. Тож крім недоліків законодавчого забезпечення права на доступ до інформації існують проблеми його застосування, а точніше - грубе порушення правових норм, яке, як показує практика, у більшості випадків $\epsilon$ безкарним. Адже подібне нехтування основоположними правами громадян, зазвичай, підтримується національним правосуддям, в Україні продовжує існувати судова вибірковість у справах, де стороною є суб'єкт владних повноважень.

Між тим, належна та справедлива практика в коментованій царині напрацьована та успішно застосовується Європейським судом з прав людини. Він неодноразово наголошував не необхідності виконання правил забезпечення режиму приватності, з урахуванням інтересів національної, громадської чи індивідуальної безпеки, для досягнення ефективності й цілісності процесу прийняття рішень владою, збереження комерційної таємниці та інших конфіденційних відомостей, без порушення основних інформаційних свобод громадян. Обов'язковими елементами для правильного застосування трискладового тесту за позицією ЄСПЛ мають бути такі: інформація повинна мати відношення до легітимної мети, передбаченої законом; оприлюднення інформації повинно загрожувати спричиненням суттєвої шкоди вказаній легітимній меті; шкода, яку може бути заподіяно вказаній меті, має бути вагомішою, ніж суспільний інтерес в отриманні інформації. Це означає, що інформація повинна бути відкритою за конкретно прописаними в законі винятками, які мають описуватися досить вузько, аби уникнути включення до них матеріалу, який насправді не шкодить легітимним інтересам. Винятки повинні базуватися на змісті конкретного документа, а не на його належності до певної категорії. Винятки також мусять враховувати темпоральний аспект, зокрема вони повинні припинити свою дію, коли загроза якомусь національному інтересу шляхом оприлюднення документа припиниться.

Але забезпеченості обмежень в інформаційному доступі наявністю легітимної мети ще не достатньо. На владний орган покладається обов'язок довести, що відкриття інформації завдасть істотної шкоди охоронюваному праву чи інтересу. При цьому вказана шкода має бути суттєво більша, ніж позитивний ефект від оприлюднення публічних відомостей. Розв'язання подібного завдання не завжди просте. Скажімо, розголошення інформації про низький рівень компетенції, корупційні методи діяльності суддів може нести загрозу репутації національної системи правосуддя, але, разом із тим, це допоможе оздоровити судівництво, посилити ефект правозастосування. Тож досить важливим є досягнення необхідного суспільно значимого балансу при здійсненні подібних оцінок. ЄСПЛ наголошує, що за державою повинна зберігатися певна свобода розсуду стосовно встановлення вказаного справедливого балансу між відповідними громадськими та приватними інтересами, які суперечать один іншому. Однак така свобода розсуду супроводжується європейським наглядом, і їі рамки залежать від характеру й значимості порушених інтересів, а також серйозності втручання6.

3 поведеного дослідження можна зробити певні висновки. Свобода інформації повинна вважатися основною рушійною силою демократичного поступу нашої держави. Втім, це не означає відкритості усіх без виключення інформаційних ресурсів держави. Адже вони часто гарантують національну безпеку, суспільні цінності та недоторканність прав фізичних осіб. Відтак, у суспільстві неодмінно виникає певний конфлікт між приватними інтересами конкретних суб'єктів на недоторканність інформації про їхню владну діяльність, персональні дані та іншої конфіденційної інформації і публічним інтересом у доступі до соціально значимих відомостей. Для вирішення вказаного конфлікту чинне законодавство та правозастосовна практика мусять напрацювати концептуальний баланс при регулюванні вказаних відносин. Зокрема, втаємничення та нерозголошення інформації повинно грунтуватися на послідовному розгляді та оцінці всіх належних обставин конкретної справи.

Маємо констатувати, що сьогодні в українських реаліях будь-яка інформація, що перебуває у державного органу, може стати конфіденційною завдяки рішенню керівника цього органу, про що в кращому випадку розпорядник даних видає якесь розпорядження, особливо не переймаючись тим фактом, що інформація, віднесена ним до обмеженої, не є такою за суттю, позаяк не відповідає критеріям, вказаним у ст. 6 спеціального закону. Також наразі абсолютно не виправдано суттєво розширився обсяг інформації, яка засекречується. Таким чином, один із заходів, спрямованих на вирішення проблеми, пов'язаної з неправомірним обмеженням права громадян на доступ до публічної інформації, це нормативне унормування застосування обмежувальних грифів доступу до інформації. За порушення правил в цій царині повинна застосовуватися цивільна відповідальність у вигляді штрафу.

${ }^{1}$ Макагонюк Ю. Реалізація права на доступ до публічної інформації у сфері екології. Национальный юридический журнал: теория и практика. 2015. Декабрь. С. 89. 


\section{Проблеми цивільного, господарського, трудового права та права соціального забезпечення}

2 Яка інформація є публічною? Центр демократії та верховенства права. 12 липня 2017 p. URL: https://cedem.org.ua/con sultations/yaka-informatsiya-ye-publichnoyu/

3 Пункт 6.2 постанови Пленуму Вищого адміністративного суду України від 29 вересня 2016 р. № 10 «Про практику застосування адміністративними судами законодавства про доступ до публічної інформації». URL: https://zakon.rada.gov.ua/ laws/show/v0010760-16

4 Принципи Артикля 19. Збірник «Міжнародні стандарти забезпечення свободи слова». Частина 2. URL: http://parlament. org.ua/2003/06/10/international-standarts-freedom-expression/

5 Справа № 800/333/17. Архів Касаційного адміністративного суду Верховного Суду за 2017 рік.

6 Рішення ЄСПЛ від 21 червня 2011 року у справі «Шимоволос проти Росії», заява 30194/09. URL: http://hrlibrary.umn. edu/russian/euro/Rshimovoloscase.html

References:

Makahoniuk, Yu. (2015). Realizatsiia prava na dostup do publichnoi informatsii u sferi ekolohii. Natsyonalnyi yurydycheskyi zhurnal: teoryia y praktyka. 88-93 [in Ukrainian]

Yaka informatsiia ye publichnoiu? Tsentr demokratii ta verkhovenstva prava.12 lypnia 2017 roku. URL: https://cedem.org.ua/ consultations/yaka-informatsiya-ye-publichnoyu/.[in Ukrainian].

Postanova Plenumu Vyshchoho administratyvnoho sudu Ukrainy vid 29 veresnia 2016 roku № 10 Pro praktyku zastosuvannia administratyvnymy sudamy zakonodavstva pro dostup do publichnoi informatsii URL: https://zakon.rada.gov.ua/laws/show/v0010760-16 [in Ukrainian].

Pryntsypy Artyklia 19. Zbirnyk «Mizhnarodni standarty zabezpechennia svobody slova». Chastyna 2. URL: http://parlament.org. ua/2003/06/10/international-standarts-freedom-expression/ [in Ukrainian].

Sprava № 800/333/17. Arkhiv Kasatsiinoho administratyvnoho sudu Verkhovnoho Sudu za 2017 rik [in Ukrainian].

Rishennia YSPL vid 21 chervnia 2011 roku u spravi «Shymovolos proty Rosii», zaiava 30194/09, URL: http://hrlibrary.umn.edu/ russian/euro/Rshimovoloscase.html [in Ukrainian].

\section{Резюме}

Гуйван П.Д. Правові засади обмеження доступу до публічної інформації.

Стаття присвячена актуальним питанням реального забезпечення здійснення інформаційних прав суб'єктів на вільний доступ до інформації, що становить публічний інтерес. В роботі аналізується зміст українських законодавчих презумпцій відкритості публічної інформації. Ставиться серйозна проблема, пов'язана з неналежним виконанням публічними розпорядниками інформації приписів закону про інформаційну свободу. Визначено чіткий перелік підстав для віднесення відомостей до розряду обмежених. Крім того, зроблено висновок, що навіть безспірне визнання певної інформації службовою і навіть таємною або конфіденційною далебі не означає, що вона не може бути надана для використання конкретній особі. Аналізуються ситуації, коли розпорядники інформації обов'язково повинні застосовувати так званий «трискладовий тест». Наведені ознаки належної та справедливої практики в коментованій царині, що застосовується Європейським судом з прав людини.

Ключові слова: відкритий доступ, публічна інформація, конфіденційні відомості.

\section{Резюме}

Гуйван П.Д. Правовые основы ограничения доступа к публичной информации.

Статья посвящена актуальным вопросам реального обеспечения осуществления информационных прав субъектов на свободный доступ к информации, составляющей публичный интерес. В работе анализируется содержание украинских законодательных презумпций открытости публичной информации. Ставится серьезная проблема, связанная с ненадлежащим исполнением публичными распорядителями информации предписаний закона об информационной свободе. Определен четкий перечень оснований для отнесения сведений к разряду ограниченных. Кроме того, в работе сделан вывод, что даже бесспорное признание определенной информации служебной, секретной или конфиденциальной, отнюдь не означает, что она не может быть предоставлена для использования конкретному лицу. Анализируются ситуации, когда распорядители информации обязательно должны применять так называемый «трехсложный тест». Приведены признаки надлежащей и справедливой практики в комментируемой области, применяемой Европейским судом по правам человека.

Ключевые слова: открытый доступ, публичная информация, конфиденциальные сведения.

\section{Summary}

Petro Guyvan. Legal basis for restricting access to public information.

The article is devoted to pressing issues of real ensuring the exercise of subjects' information rights to free access to information of public interest. It is emphasized that the proper organization of the turnover and the legal protection of the transparent dissemination of information are the basic foundations for achieving the goals of the socio-economic and cultural development of the country, improving the quality of life. After all, the ability of each member of society to obtain data on public relations in the society guarantees the strengthening of a single information space, minimizing various negative manifestations in the activities of the authorities, such as abuse, negligence, corruption.

The content of Ukrainian legislative presumptions of openness of public information is analyzed in the paper. As a general rule, such information is open. Exceptions to this rule are laid down by law, in particular, the types of information that may be restricted confidential, classified and proprietary information, and a set of requirements that are compulsory to restrict access to such types of information. The stated restrictions on the turnover of certain data are quite weighted, they can only take place when the fundamental principles of the state and national security, inalienable fundamental human rights, are affected.

There is a serious problem related to the misapplication of information by the public stewards of the information law requirements. Examples are given where state and local government officials make every effort to conceal their activities, thus concealing their mistakes, and often abuses. This is accompanied by their support from national judiciary. The normative and practical principles of 
organizing the public activity of the authorities regarding compliance with the law in limiting access to classified, confidential and official information are considered. A clear list of reasons for attributing information to the category of restricted persons is defined. It also examines the essence of the legislature's basic democratic approach whereby any possibility of restricting access to information can arise only when the restriction is made solely in the interests of national security, public order or the protection of the rights of others; disclosure of information may cause significant harm to those interests; the harm of disclosing such information outweighs the public interest in obtaining it. It is emphasized that the law indicates the mandatory presence of a set of these features.

In addition, the paper concludes that even the indisputable recognition of certain information as official or even secret or confidential does not mean that it cannot be provided for use by a specific person. Information cannot be denied only because the relevant type of information is included in the list of information that constitutes business information. In the case of public need for this information, they may also be made publicly available: in each case where a particular information is given the status of "official use" of the information manager, the so-called "three-part test" must be applied. The content of such testing and its specific manifestations are analyzed. The refusal to satisfy the request for information must be reasoned, that is, the refusal of the information manager is obliged to justify the existence of grounds for restriction in access, which constitute the content of the "three-part test". The following are indications of good and fair practice in the commentary field applied by the European Court of Human Rights.

Key words: open access, public information, confidential information.

DOI: $10.36695 / 2219-5521.2 .2019 .23$

УДК 347.672

\section{М.O. МИХАЙЛІВ}

Марія Омелянівна Михайлів, кандидат юридичних наук, доцент, доцент Львівського національного університету імені Івана Франка*

ORCID: 0000-0002-5007-7810

\section{УНІФІКАЦІЯ КОЛІЗІЙНИХ НОРМ У СФЕРІ СПАДКОВИХ ВІДНОСИН}

Постановка проблеми. Найбільш дієвим інструментом правового регулювання спадкових відносин у міжнародному приватному праві, окрім інших видів джерел, $є$ міжнародні договори. На сьогодні міжнародні договори залишаються чи не єдиним в Україні найбільш ефективним способом уніфікації норм у сфері спадкування, що допомагає усунути розбіжності як між матеріальними, так і між колізійними нормами держав у даній сфері.

Аналіз останніх досліджень і публікацій з даної теми. Питанням уніфікації норм у сфері спадкових відносин в міжнародному приватному праві приділяли увагу ряд українських та іноземних вчених, таких, наприклад, як: М.І. Браун, Г.В. Галущенко, І.Г. Гетьман-Павлова, Н.Г. Вілкова, Г.К. Дмитрієва, А.С. Довгерт, О.О. Кармаза, В.І. Кисіль, Л.А. Лунц, І.Г. Медведєв, Н.В. Орлова, А.А. Рубанов, А.А. Степанюк, В.Л. Толстих, С.І. Фурса, С.А. Фурса, А.Г. Хачатурян та ін. Проте в науці ще залишається чимало питань, які потребують дослідження та є актуальними і на сьогодні.

Мета статті. Визначити поняття та правову природу уніфікації в міжнародному приватному праві. Проаналізувати зміст норм міжнародних договорів та визначити місце, яке вони займають серед джерел міжнародного приватного права у врегулюванні відносин міжнародного спадкування. Виокремити проблеми колізійного регулювання міжнародних спадкових відносин в міжнародних договорах та запропонувати шляхи їх вирішення.

Виклад основного матеріалу. Спадкові відносини, ускладнені іноземним елементом, за своїм характером є складними, оскільки завжди пов'язані із правопорядками двох або більше держав. А це, в свою чергу, призводить до появи проблем їх належного правового регулювання.

Суб'єкти спадкових відносин, як правило, стикаються з труднощами, пов'язаними із вибором матеріального права, яке має застосовуватися до правовідносин у сфері спадкування. Саме колізійні норми і $є$ тим інструментом, який має своїм завданням визначити, право якої держави буде застосовним до приватноправових відносин з іноземним елементом. Проте за змістом колізійні норми у сфері спадкування іноземних держав різняться, або ж вони взагалі відсутні, а це, в свою чергу, вказує на потребу в уніфікації таких норм на міжнародному рівні.

Відсутність єдиних колізійних норм спадкування та збігу з колізійними нормами інших правопорядків, на думку М. Брауна, може призвести до того, що особа втратить право спадкувати. Поки не існує єдиної системи колізійного права, доля кожних правовідносин піддається випадковості. Різноманіття колізійних норм завдає удару сучасній правосвідомості ${ }^{1}$.

Ідея уніфікації колізійних норм зародилася ще наприкінці XIX ст. як теорія універсалістів. Проте і на сьогодні втілити цей задум не вдалося. Неоднозначні погляди вчених можемо спостерігати і щодо питань,

(C) М.О. Михайлів, 2019

* Mariya Mykhailiv, Ph.D. in Law, Associate professor, Associate professor of Ivan Franko of Lviv National University 